\title{
THE STORMS IN RIO DE JANEIRO CITY IN APRIL 2010
}

\author{
Fabio Gomes Coelho ${ }^{1}$ \\ Mônica de Aquino G. Massera da Hora ${ }^{2}$ \\ Antonio Ferreira da Hora
}

\begin{abstract}
The Rio de Janeiro City suffered great floods due to the storms that took place between April 5 th and 6th 2010. According to the official information, the total accumulated in 24 hours was $278 \mathrm{~mm}$ (considered the worst flood in 44 years, since 1966) and the high tide also contributed to the 60 flooding points verified in the whole city. The purpose of the present work is to compare the daily maximum rainfall (P1day) available in Agência Nacional de Águas (ANA) database with the data from the Fundação de Geotécnica da Cidade do Rio de Janeiro (GEO-RIO) rain gauges network and historical records. The precipitation gauges registered in ANA and selected for the study were SABÓIA LIMA; IRAJÁ; PRAÇA XV and JARDIM BOTÂNICO and the P1day values found were, respectively, 330.9mm (02/26/1971); $339.6 \mathrm{~mm}(02 / 26 / 1971) ; 237.0 \mathrm{~mm}(01 / 11 / 1966)$; and, 242.6mm (01/11/1966). The selected stations from GEO-RIO were TIJUCA; SAÚDE and JARDIM BOTÂNICO and the P1day values found were, respectively, 259.9mm (01/08/1998); 160.8mm (10/24/2007); and 239.0mm (04/06/2010). For the same days, is also presented an analysis of the recorded tides, observed by Diretoria de Hidrografia e Navegação - DHN, which is a Brazilian navy organization, as a complement to understand the phenomenon. In conclusion, it was possible to infer that April 2010 event was overcome twice in the last 40 years (February, 1971 and January, 1998).
\end{abstract}

Keywords: floods, daily maximum rainfall, Rio de Janeiro, April 2010.

\section{INTRODUCTION}

Rio de Janeiro City occupies the western coast of Guanabara Bay and some of its islands (like Governador and Paquetá), and has developed on strait alluvial plans, compressed between mountains and hills. Part of the city is located in low areas and on the margin of beaches, lakes, rivers and Guanabara Bay. Its formation and occupation favored, through the time, several floods of different proportions, registered along its history.

On April 5th and 6th of 2010, strong rains affected Rio de Janeiro City that suffered, mainly, with major floods and sliding of slopes. According to CPTEC/INPE (2010), the rain was due to a cold air mass that caused significant tempera- ture fall. This cold front with a moist mass of air (maritime) met the unstable humid air mass that were already upon the Southeast and caused the entire observed rainstorm.

An official note was published informing that the rainstorm was the strongest since 1966 (rainfall index of $245 \mathrm{~mm}$ ), causing the worst flood in 44 years. However caution is needed in comparisons, as well as all of the variables that influence the floods, as in the case of the analyzed rain which are, among many others: tide, drainage system, precipitation and infiltration area. The proportion of the damages is not due to the precipitation only, which therefore, for this reason, cannot be called the highest.

\footnotetext{
${ }^{1}$ Undergraduate student of Water Resources and Environment Engineering, Universidade Federal Fluminense, fabiogomescoelho@hotmail.com

2 Water Resources and Environment Professors and Researches, Universidade Federal Fluminense, Rua Passo da Pátria, 156 Bloco - D - Escola de Engenharia - sala 133, Niterói - RJ, Brasil, dahora@vm.uff.br
} 


\section{HISTORICAL EVOLUTION OF FLOODS IN THE RIO DE JANEIRO CITY}

According to BARROS (2002), the cradle of Rio de Janeiro City was the Castelo hill, chosen by Mem de Sá in 1567 to shelter Portugueses who had participated in the expulsion of the French commanded by Villegaignon. Then, the first residents began to leave the beach between Cara de Cão and Pão de Açúcar hills, site of the city's foundation, and they occupied the most strategic point around the bay: a high plain stuck in soggy, initially called São Januário hill and after Castelo hill. Thus was born the city, delimited and squeezed into a hill with features almost insular.

The first big flood registered occurred in April 14th, 1756, when canoes were used as mean of transport through the city streets. The relate by FAZENDA (1904) is transcript to follow:

“... Em 14 de abril de 1756, depois de 1 hora da tarde, choveu tão grossa e copiosa chuva, precedida de vehementes concussóes do ar e espantosos furacões, por tres dias, sem interrupção,... desde a primeira noite muita gente desamparou as casas, as quaes cairam, fugindo sem tino para as egrejas; desde então as aguas cresceram por tal maneira, que inundaram a rua dos Ourives e entraram pelas casas dentro, por não caberem pela valla. No dia 15 , saindo o Sanctissimo da Sé, o sacerdote, que levava o Senhor, foi descalço, e bem assim os ermãos da Irmandade do Sanctissimo; todo o campo parecia um lagamar, vadeavam-se as ruas de, canóas, no dia 16 u'ma navegou desde o Valongo até a Sé (que estava na egreja do Rosario, dos pretos) com sete pessoas."

In 1811, the rains occurred between February 10th and 17th, known as "as águas do monte" toppled part of the Castelo and with it, also many houses. The magnitude of the rainstorm was such that the Regent Prince Dom João ordered that the churches kept opened to shelter the homeless and requested studies about the reasons of the catastrophe, [FAZENDA, 1904].

According to the data from CBMERJ (2010), in 03/17/1906, the overflow of Mangue channel caused flood in almost the whole city and collapses with deaths in Santa Tereza, Santo Antônio and Gamboa hills. The storm totalized $165 \mathrm{~mm}$ in 24 hours. In $01 / 29 / 1940,112 \mathrm{~mm}$ caused underflow in almost the whole city and deaths caused by crumble in Santo Cristo quarter. In $01 / 06 / 1942$, was $132 \mathrm{~mm}$ of rain, with a crumble that buried 5 people on Salgueiro hill. In 01/15/1962, a rainstorm that totalized $242 \mathrm{~mm}$ caused the overflow of Mangue channel, Maracanã river and slip in many places. In $01 / 11 / 1966$, the flood on Guanabara state and Rio de Janeiro City left a toll of 250 deaths and 50.000 homeless. In 01/20/1967, a collapse provoked the sliding of a house and two buildings between Belizário Távora and General Glicério streets, in Laranjeiras neighborhood, with 200 deaths and 300 hurts. In 1971, according to VEJA journals, in only 24 hours of storm, the Penha pluviometer registered $290 \mathrm{~mm}$, a "real record". In 12/03/1982, the rains caused the death of 6 people and mudslide on Pau da Bandeira hill, inundating several streets with the overflow of Faria-Timbó River. In 03/20/1983, a strong rainstorm provoked the crumbling of houses and the death of 5 people on Santa Teresa, where the rain reached $189 \mathrm{~mm}$. The overflow of rivers and channels in Jacarepaguá left more than 150 homeless. On the week of the day 02/12/1988, the rains provoked sliding on Dona Marta hill with a result of 6 deaths, 40 hurts and 300 homeless. The heavy rain destroyed about 30 huts.

\section{METHODOLOGY}

\subsection{ANALYSIS OF THE OBSERVED PRECIPITATION DATA}

To evaluate the magnitude of precipitation heights observed on Rio de Janeiro City, a survey of the historical rain series was done in the database available on ANA and GEO-RIO, two public institutions that own and operate precipitation gauges, providing to the public the observed series. It is important to point out that most of the precipitation gauges are deactivated and with failures, being possible to recover series until 90 's, as shown on Table 1. 
Table 1 - Geographical Position of the Precipitation Gauges Available on ANA Database

\begin{tabular}{|c|c|c|c|c|c|c|}
\hline \multirow{2}{*}{ Code } & \multirow{2}{*}{ Name } & \multirow{2}{*}{ Latitude } & \multirow{2}{*}{ Longitude } & Altitude & \multicolumn{2}{|c|}{ Period of Observation } \\
\cline { 5 - 7 } & & & & Start & End \\
\hline 2243076 & SABOIA LIMA & $-22: 56: 10$ & $-43: 14: 40$ & 100 & $01 / 01 / 1967$ & $12 / 01 / 1994$ \\
\hline 2243086 & IRAJÁ - 3DR & $-22: 49: 50$ & $-43: 19: 46$ & 6 & $01 / 01 / 1965$ & $12 / 01 / 1994$ \\
\hline 2243129 & PRACA XV & $-22: 54: 00$ & $-43: 10: 00$ & 5 & $01 / 01 / 1961$ & $10 / 01 / 1991$ \\
\hline 2243168 & JARDIM BOTÂNICO & $-22: 58: 00$ & $-43: 13: 00$ & 5 & $01 / 01 / 1961$ & $12 / 01 / 1970$ \\
\hline
\end{tabular}

The data available refers to the daily maximum precipitation (P1day) and the values are transcript on Table 2. It is important to point out that the years that shown failures were not considered.

Table 2 - ANA- Daily Maximum Precipitation (P1day)

\begin{tabular}{|c|c|c|c|c|c|c|c|}
\hline \multicolumn{2}{|c|}{ SABOIA LIMA } & \multicolumn{2}{|c|}{ IRAJÁ - 3DR } & \multicolumn{2}{|c|}{ PRAÇA XV } & \multicolumn{2}{|c|}{ JARDIM BOTÂNICO } \\
\hline Date & $\begin{array}{r}\text { P1day } \\
(\mathrm{mm})\end{array}$ & Date & $\begin{array}{l}\text { P1day } \\
(\mathrm{mm})\end{array}$ & Date & $\begin{array}{l}\text { P1day } \\
(\mathrm{mm})\end{array}$ & Date & $\begin{array}{l}\text { P1day } \\
(\mathrm{mm})\end{array}$ \\
\hline 03/18/68 & 110.1 & $03 / 20 / 65$ & 74.3 & $03 / 02 / 61$ & 61.9 & $02 / 19 / 62$ & 171.4 \\
\hline $04 / 03 / 69$ & 75.1 & $03 / 27 / 66$ & 179.4 & $01 / 16 / 62$ & 167.4 & $03 / 30 / 63$ & 109.7 \\
\hline $01 / 10 / 70$ & 52.2 & $02 / 20 / 67$ & 131.5 & $12 / 30 / 63$ & 55.1 & $05 / 05 / 63$ & 59.2 \\
\hline $02 / 26 / 71$ & 330.9 & $12 / 02 / 68$ & 102.2 & $12 / 18 / 64$ & 69.6 & $12 / 04 / 64$ & 69.9 \\
\hline $04 / 05 / 72$ & 52.6 & $01 / 25 / 69$ & 83.8 & $03 / 04 / 65$ & 111.4 & $03 / 04 / 65$ & 152.8 \\
\hline $07 / 19 / 73$ & 91.5 & $02 / 26 / 71$ & 339.6 & $01 / 11 / 66$ & 237.0 & $01 / 11 / 66$ & 242.6 \\
\hline $12 / 04 / 74$ & 69.4 & $01 / 17 / 73$ & 100.0 & $02 / 19 / 67$ & 154.6 & $12 / 02 / 68$ & 113.6 \\
\hline $05 / 04 / 75$ & 89.7 & $12 / 26 / 75$ & 62.0 & $12 / 02 / 68$ & 73.6 & $01 / 10 / 70$ & 64.0 \\
\hline $05 / 01 / 76$ & 147.0 & $12 / 21 / 76$ & 53.8 & $03 / 27 / 69$ & 52.8 & & \\
\hline $04 / 02 / 77$ & 136.5 & $02 / 07 / 78$ & 49.3 & $03 / 14 / 70$ & 54.8 & & \\
\hline $02 / 08 / 78$ & 95.3 & $12 / 27 / 79$ & 59.2 & $05 / 04 / 75$ & 123.6 & & \\
\hline $01 / 23 / 79$ & 124.7 & $02 / 14 / 80$ & 70.2 & $02 / 01 / 76$ & 51.2 & & \\
\hline $10 / 13 / 80$ & 85.1 & $12 / 03 / 81$ & 73.0 & $03 / 20 / 83$ & 125.6 & & \\
\hline $12 / 03 / 81$ & 213.9 & $01 / 03 / 82$ & 66.8 & $04 / 04 / 87$ & 102.2 & & \\
\hline $03 / 20 / 83$ & 114.4 & $11 / 05 / 83$ & 96.8 & & & & \\
\hline $03 / 31 / 84$ & 63.4 & $01 / 31 / 85$ & 121.0 & & & & \\
\hline $11 / 05 / 85$ & 101.1 & $04 / 23 / 86$ & 60.9 & & & & \\
\hline $04 / 23 / 86$ & 112.8 & $01 / 04 / 90$ & 71.7 & & & & \\
\hline $06 / 07 / 87$ & 75.4 & $04 / 19 / 90$ & 151.5 & & & & \\
\hline $02 / 22 / 88$ & 152.4 & $01 / 05 / 92$ & 119.5 & & & & \\
\hline $06 / 12 / 89$ & 160.0 & $12 / 11 / 93$ & 56.0 & & & & \\
\hline $04 / 19 / 90$ & 201.0 & $03 / 27 / 94$ & 77.2 & & & & \\
\hline $05 / 07 / 91$ & 237.9 & & & & & & \\
\hline $11 / 27 / 92$ & 100.8 & & & & & & \\
\hline $03 / 06 / 93$ & 107.8 & & & & & & \\
\hline
\end{tabular}


Then, a survey about the information included the database of GEO-RIO from the precipitation gauges called SAÚDE, TIJUCA and JARDIM BOTÂNICO which positions and observed values are shown Tables 3 and 4, respec- tively. The beginning of the operation was in 1997 and the data of each station are relayed after a 15 minutes interval, through radio, to a master station. The precipitation is measured in a $0.2 \mathrm{~mm}$ resolution.

Table 3 - Geographical Positions of the Precipitation Gauges Available on GEO-RIO Database

\begin{tabular}{|c|c|c|c|c|c|}
\hline \multirow{2}{*}{ Name } & \multirow{2}{*}{ Latitude } & Longitude & \multirow{2}{*}{$\begin{array}{c}\text { Altitude } \\
(\mathbf{m})\end{array}$} & \multicolumn{2}{|c|}{ Period of Observation } \\
\cline { 5 - 6 } & & & Start & End \\
\hline TIJUCA & $-22: 55: 55$ & $-43: 13: 18.5$ & 340 & $01 / 01 / 1997$ & - \\
\hline SAÚDE & $-22: 54: 52,6$ & $-43: 11: 40,3$ & 35 & $01 / 01 / 1997$ & - \\
\hline JARDIM BOTÂNICO & $-22: 58: 21,7$ & $-43: 13: 26.4$ & 0 & $01 / 01 / 1997$ & - \\
\hline
\end{tabular}

Table 4 - GEO-RIO - Daily Maximum Precipitation (P1day)

\begin{tabular}{|c|c|c|c|c|c|}
\hline \multicolumn{2}{|c|}{ SAÚDE } & \multicolumn{2}{c|}{ TIJUCA } & \multicolumn{2}{c|}{ JARDIM BOTÂNICO } \\
\hline Date & P1day $(\mathrm{mm})$ & Date & P1day $(\mathbf{m m})$ & Date & P1day $(\mathbf{m m})$ \\
\hline $01 / 05 / 97$ & 34.4 & $04 / 05 / 97$ & 47.9 & $08 / 06 / 97$ & 52.3 \\
\hline $01 / 07 / 98$ & 62.1 & $01 / 08 / 98$ & 259.9 & $01 / 08 / 98$ & 194.0 \\
\hline $04 / 21 / 99$ & 65.1 & $06 / 06 / 99$ & 62.2 & $01 / 15 / 99$ & 68.3 \\
\hline $02 / 16 / 00$ & 85.9 & $09 / 03 / 00$ & 81.2 & $12 / 01 / 00$ & 137.8 \\
\hline $12 / 24 / 01$ & 106.0 & $12 / 24 / 01$ & 188.4 & $12 / 24 / 01$ & 83.0 \\
\hline $12 / 09 / 02$ & 77.8 & $12 / 09 / 02$ & 106.8 & $06 / 23 / 02$ & 84.2 \\
\hline $03 / 17 / 03$ & 91.8 & $11 / 02 / 03$ & 136.8 & $01 / 24 / 03$ & 104.0 \\
\hline $12 / 11 / 04$ & 38.6 & $01 / 01 / 04$ & 110.8 & $11 / 07 / 04$ & 94.0 \\
\hline $02 / 04 / 05$ & 79.8 & $12 / 11 / 05$ & 97.6 & $03 / 03 / 05$ & 102.6 \\
\hline $01 / 27 / 06$ & 113.8 & $04 / 17 / 06$ & 220.2 & $05 / 23 / 06$ & 108.2 \\
\hline $10 / 24 / 07$ & 160.8 & $10 / 24 / 07$ & 163.2 & $10 / 24 / 07$ & 133.2 \\
\hline $03 / 14 / 08$ & 64.2 & $04 / 15 / 08$ & 85.6 & $01 / 21 / 08$ & 74.8 \\
\hline $01 / 21 / 09$ & 85.4 & $01 / 21 / 09$ & 117.0 & $12 / 10 / 09$ & 99.2 \\
\hline $04 / 05 / 10$ & 88.4 & $04 / 05 / 10$ & 115.8 & $04 / 05 / 10$ & 123.6 \\
\hline $04 / 06 / 10$ & 123.6 & $04 / 06 / 10$ & 213.2 & $04 / 06 / 10$ & 239.0 \\
\hline
\end{tabular}

Due the data are accumulated every 15 minutes, it was also possible to estimate the 24-hour maximum rainfall (P24h) between April 5th and 6th, and the values resulted in $280.2 \mathrm{~mm}$ (TIJUCA); $189.4 \mathrm{~mm}$ (SAÚDE) and 303.0mm (JARDIM BOTÂNICO), Table 5.

Table 5 - GEO-RIO - Maximum 24-hour Rainfall

\begin{tabular}{|c|c|c|c|c|c|}
\hline \multicolumn{2}{|c|}{ SAÚDE } & \multicolumn{2}{|c|}{ TIJUCA } & \multicolumn{2}{c|}{ JARDIM BOTÂNICO } \\
\hline Date and Hour & P24h $(\mathrm{mm})$ & Date and Hour & P24h $(\mathrm{mm})$ & Date and Hour & P24h $(\mathrm{mm})$ \\
\cline { 6 - 7 } \cline { 5 - 6 } & 189.4 & $04 / 05 / 10-18: 15$ & 280.2 & $04 / 05 / 10-18: 04$ & 303.0 \\
\hline
\end{tabular}




\subsection{ANALYSIS OF THE OBSETIDE DATA}

To understand how the drainage of Rio de Janeiro City was influenced by the tide level, data observed by SE200 gauge from Ilha Fiscal station, under DHN responsibility, were analyzed. Table 6 shows the gauge position.

Table 6 - DHN - Geographical Position of the Tide Gauge

\begin{tabular}{|c|c|c|c|c|c|}
\hline \multirow{2}{*}{ Code } & \multirow{2}{*}{ Name } & \multirow{2}{*}{ Latitude } & \multirow{2}{*}{ Longitude } & \multicolumn{2}{|c|}{ Period of Observation } \\
\cline { 5 - 6 } & & & Start & End \\
\hline 50140 & ILHA FISCAL & $-22: 53: 8$ & $-43: 10: 0$ & $01 / 01 / 2010$ & - \\
\hline
\end{tabular}

The data available refers to the tide observed as a result of the astronomical and meteorological tide, Figure 1.

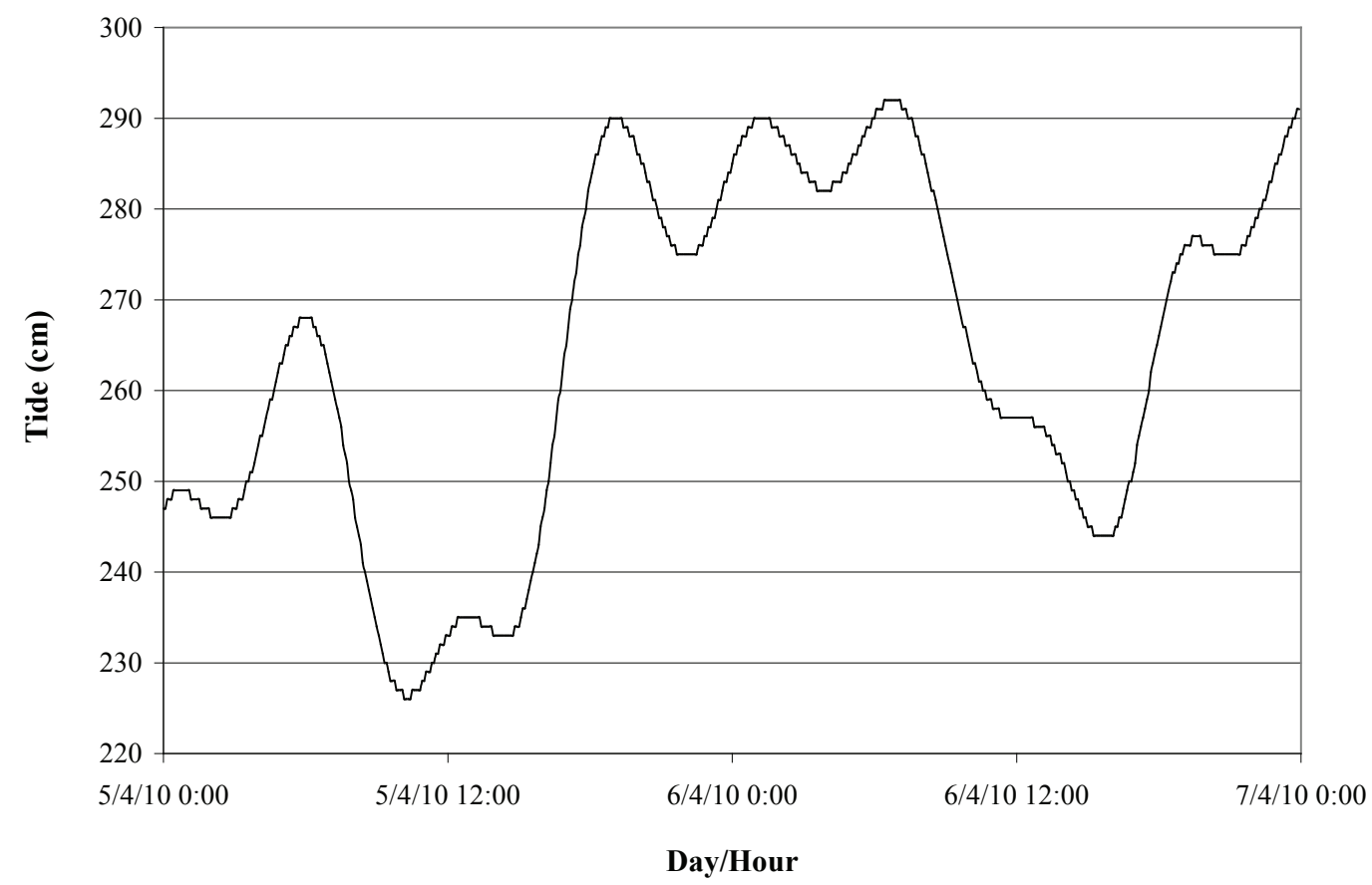

Figure 1 - Observed Tide - April 5th and 6th, 2010

The average levels observed on April and in the first semester of 2010 were 241.57 and $233.01 \mathrm{~cm}$, respectively. On day 5 , the average was $255.31 \mathrm{~cm}$ and the maximum value $290.00 \mathrm{~cm}$ while on day 6 , the average was $272.82 \mathrm{~cm}$ and the maximum $292.00 \mathrm{~cm}$.

\section{CONCLUSION}

The history of rainfall presented shows that the rains with significant intensities are not unpublished facts for residents of the Rio de Janeiro
City as the urban infrastructure is not ready to large proportion of pluviometer events.

The analyzed data showed that the highest daily rainfall recorded was on February 26, 1971, $339.6 \mathrm{~mm}$ (IRAJÁ-3DR) followed by $259.9 \mathrm{~mm}$ (TIJUCA), January 8th, 1998 and $242.6 \mathrm{~mm}$ (JARDIM BOTÂNICO), November 1st, 1966.

Among the rainfall data collected for days 5th and 6th April, 2010, the most relevant was observed was JARDIM BOTÂNICO gauge, which recorded $239.0 \mathrm{~mm}$ (P1 day) and $303.0 \mathrm{~mm}$ (P24h). On TIJUCA gauge, the observed values 
were $213.2 \mathrm{~mm}$ (P1day) and $280.2 \mathrm{~mm}$ (P24h). On SAÚDE gauge, the observed values were $88.4 \mathrm{~mm}$ (P1day) and $189.0 \mathrm{~mm}$ (P24h). The rain started in all three gauges around 18:00.

A relevant observation is that the tide level was $284 \mathrm{~cm}$ at $18: 05$ and $290 \mathrm{~cm}$ at $18: 50$ and last at least 30 minutes. From this moment until 22:00, the level tide average was $281.40 \mathrm{~cm}$. From $18: 00$ to $22: 00$, occurred a precipitation of $87.0 \mathrm{~mm}$.

In conclusion, the rains the attendant flooding, landslides, homeless and deaths - take place frequently in Rio, so it is urgent to project an adequate urban expand and modernize the drainage systems, avoiding the "blame-game", when public accusing the government neglect and the government accusing the poor who choose to illegally invade dangerous hillsides and build homes there.

\section{BIBLIOGRAPHY}

BARROS, P. C.(2002), “Onde nasceu a cidade do Rio de Janeiro? (um pouco da história do Morro do Castelo)", Journal of geo-paisagem, Vol. 1, No.2. available at: http://www.feth.ggf.br/origem $\% 20 \mathrm{do} \% 20$ rio\%20de\%20janeiro.htm (acessed 01 June 2010).
FAZENDA, J. V (1904), “Antiqualhas e Memórias do Rio de Janeiro", Journal of Instituto Histórico Geográfico Brasileiro, Vol. 86, pp. 140.

ANA, HidroWeb. "Dados hidrológicos, estações", available at: http://hidroweb.ana.gov.br/HidroWeb. asp? TocItem $=1070 \&$ TipoReg $=7 \&$ MostraCon $=$ false $\&$ CriaArq $=$ false $\&$ TipoArq $=1 \&$ SerieHist=false $\quad($ ac cessed 22 June 2010).

GEORIO, "Alerta Rio. Consulta de Dados pluviométricos da Cidade do Rio de Janeiro", available at:: http://www2.rio.rj.gov.br/georio/site/alerta/ download.htm (accessed 22 June 2010).

CBMERJ, "Rio de Janeiro - as grandes enchentes desde 1.711", available at: http://aleosp2008.wordpress.com/2008/11/29/rio-de-janeiro-as-grandesenchentes-desde-1711 (accessed 22 June 2010).

CPTEC/INPE, "Síntese Sinótica Mensal. Abril de 2010", available at: http://www7.cptec.inpe. $\mathrm{br} / \sim$ rupload/arquivo/Sintese_abril_10.pdf (accessed 10 August 2010). 